\title{
Myrsinionosides A-E: Megastigmane Glycosides from the Leaves of Myrsine seguinii LEv.
}

\author{
Hideaki Otsuka, ${ }^{* a}$ Xi-Ning Zhong, ${ }^{a}$ Eiji Hirata, ${ }^{b}$ Takakazu Shinzato, ${ }^{c}$ and Yoshio TakedA ${ }^{d}$ \\ Institute of Pharmaceutical Sciences, Hiroshima University Faculty of Medicine, ${ }^{a}$ 1-2-3 Kasumi, Minami-ku, Hiroshima \\ 734-8551, Japan, Faculty of Agriculture, University of the Ryukyus, ${ }^{b} 1$ Senbaru, Nishihara-cho, Nakagami-gun, Okinawa \\ 903-0129, Japan, University Forest, Faculty of Agriculture, University of the Ryukyus, ${ }^{c} 685$ Aza Yona, Kunigami-son, \\ Kunigami-gun, Okinawa 905-1427, Japan, and Faculty of Integrated Arts and Sciences, the University of Tokushima, ${ }^{d} 1-1$ \\ Minamijosanjima-cho, Tokushima 770-8502, Tokushima, Japan. Received March 8, 2001; accepted May 25, 2001
}

Eight megastigmane glycosides were isolated from the leaves of Myrsine seguinii collected in Okinawa. Three of them were found to be known compounds, i.e., ampelopsisionoside, alangionoside $J$, and linarionoside A. The structures of the new megastigmane glycosides were elucidated from the spectroscopic data and their absolute stereochemistries were determined in detail using a modified Mosher's method.

Key words Myrsine seguinii; Myrsinaceae; myrsinionoside; megastigmane glycoside; modified Mosher's method

More than 10 species belonging to the Myrsinaceae are distributed in temperate and subtropical areas of Japan. ${ }^{1)}$ Plants in this family are generally used as anthelmintics, ${ }^{2)}$ and in China Ardisia japonica is used as an antitussive, expectorant, antidote and diuretic. ${ }^{3)}$ Myrsine seguinii (syn. Rapanea neriifolia) is known to contain rapanone, which is isolated from stem bark, and also used as an anthelmintic for cattle. Antiviral activity has been found in crude extracts of M. australis and M. salicina growing in New Zealand. ${ }^{4)}$

From the leaves of M. seguinii, collected in Okinawa, flavonol glycosides, lignan sulfate and arbutin derivatives have been isolated. ${ }^{5)}$ Although quantitative analysis was not performed, the content of arbutin, which is currently used in cosmetics as an antioxidant, seemed to be fairly high. ${ }^{5 c}$ On further extensive phytochemical investigation, several megastigmane glycoside derivatives, which comprise a currently expanding family, were isolated. This paper deals with their structural elucidation.

\section{Results and Discussion}

A $n$-BuOH-soluble fraction obtained by solvent partitioning of a MeOH extract of the leaves of Myrsine seguinii was separated by column chromatography on a highly porous synthetic resin (HP-20), and normal and reversed-phase silica gels, and by liquid-liquid partition chromatography to afford compounds $\mathbf{1}-\mathbf{8}$ in the yields shown in the experimental section.

Compound 1, $[\alpha]_{\mathrm{D}} c a .0^{\circ}$, was isolated as an amorphous powder and was identified as ampelopsisionoside, which has been isolated from Ampelopsis brevipedanculata, ${ }^{6}$ by NMR, high-resolution (HR) FAB-MS, and circular dichroism (CD) spectroscopic analyses. However, a relatively large specific optical rotation value $\left([\alpha]_{\mathrm{D}}-35.1^{\circ}\right)$ was reported for 1 . An analogous compound, $6^{\prime}-O-\beta$-D-xylopyranosyl ampelopsisionoside (platanionoside $\mathrm{C}$ ), isolated from Alangium platanifolium var. platanifolium, showed an $[\alpha]_{\mathrm{D}}$ value of $-26.0^{\circ}{ }^{6 b)}$ The $[\alpha]_{\mathrm{D}}$ value for 1 was calculated from that of $6^{\prime}-O-\beta$-D-xylopyranosyl ampelopsisionoside to be nearly $-7^{\circ}$, using the Klyne rule, ${ }^{7)}$ when the $[\mathrm{M}]_{\mathrm{D}}$ value of methyl<smiles>CC(C)[C@H](C)/C=C/[C@@]1(O)[C@@H](C)CC(=O)C[C@H]1C</smiles><smiles>[R6]C1CC(C)=C(CCC(C)[18O])C(C)(C)C1</smiles><smiles>CO[C@@H](C)CC[C@@]1(C)[C@@H](C)CC(=O)CC1(C)C</smiles>

$\mathbf{R}_{1} \quad \mathbf{R}_{2}$ $2 \mathrm{H} \quad \mathrm{Gle}$ 2a ${ }_{3}$ OH $\quad$ Gle(OAC) Gis
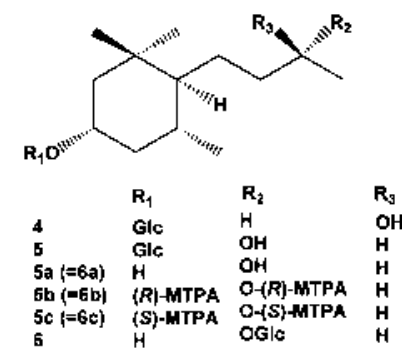

Fig. 1. Structures 
$\beta$-D-xylopyranoside is $-108^{\circ}$. Thus the current value for $[\alpha]_{\mathrm{D}}$ might be of more accuracy.

Myrsinionoside A (2) was isolated as an amorphous powder and its elemental composition was determined to be $\mathrm{C}_{19} \mathrm{H}_{34} \mathrm{O}_{7}$ by negative-ion HR-FAB-MS. The IR spectrum of 2 showed an absorption band at $1702 \mathrm{~cm}^{-1}$ ascribable to ketone, and strong absorption bands at 3429 and $1078 \mathrm{~cm}^{-1}$ suggestive of a glycosidic structure. The ${ }^{1} \mathrm{H}$ - and ${ }^{13} \mathrm{C}-\mathrm{NMR}$ spectra of $\mathbf{2}$ showed six signals for a $\beta$-glucopyranosyl unit, and two tertiary methyls at a geminal position, two secondary methyls, four methylenes, one methine with and two methines without a hydroxyl group, a quaternary carbon atom, and a ketone function $\left(\delta_{\mathrm{C}} 214.5\right)$. On acetylation with acetic anhydride and pyridine, $\boldsymbol{2}$ gave a tetraacetate. These findings led us to formulate the megastigmane skeleton for $\mathbf{2}$. ${ }^{1} \mathrm{H}-{ }^{1} \mathrm{H}$ correlation spectroscopy (COSY) and heteronuclear single-quantum correlation (HSQC) spectroscopy showed that one of the methylenes was at an isolated position, and the remaining methylenes and methines were present in a sequential manner, forming the carbon chain from $\mathrm{C}-4$ to $\mathrm{C}-10$. Heteronuclear multiple-bond correlation (HMBC) spectroscopy (Fig. 2) confirmed that the structure of $\mathbf{2}$ is megastigman-3-on-9-ol $O$ - $\beta$-glucopyranoside. Since the axial proton $\left(\delta_{\mathrm{H}} 2.22\right)$ at C-4 appeared as a triplet $(J=14 \mathrm{~Hz})$, $\mathrm{H}-5\left(\delta_{\mathrm{H}} 1.78\right)$ must occupy the axial space. However, the coupling constant between H-5 and H-6 $\left(\delta_{\mathrm{H}} 1.14\right)$ was obscure, because both appeared as multiplets. Thus phase-sensitive nuclear Overhauser enhancement spectroscopy (PHNOESY) was performed to determine the relative orientation of the side chain. Since the axial methyl protons $\left(\delta_{\mathrm{C}} 0.761\right)$ on $\mathrm{C}-11$ crossed methylene proton(s), either one at C-7 or two (or one) at $\mathrm{C}-8$, the side chain must be in the equatorial orientation. The absolute configuration of $\mathrm{C}-5$ was determined to be $R$ from the CD spectrum, in which a positive Cotton effect was observed at $\left.282 \mathrm{~nm}([\theta]+871),{ }^{6}\right)$ and, in turn, that of C-6 to be $S$. That of C-9 was expected to be $R$ from the $\beta$-D-glucosylation-induced shift trend in ${ }^{13} \mathrm{C}-\mathrm{NMR}$ spectroscopy. ${ }^{8)}$ Actually 2 was hydrolyzable by $\beta$-D-glucosidase (emulsin) to an aglycone and D-glucose. Therefore, the structure of 2 was fully established, namely $(5 R, 6 S, 9 R)$ megastigma-3-on-9-ol $O$ - $\beta$-D-glucopyranoside.

Myrsinionoside B (3) was isolated as an amorphous powder, and its elemental composition, $\mathrm{C}_{19} \mathrm{H}_{34} \mathrm{O}_{8}$, analyzed by HR-FAB-MS and other spectral data indicated that $\mathbf{3}$ was also a megastigmane glucoside with one oxygen atom more than 2. The strong IR absorption band at $1698 \mathrm{~cm}^{-1}$ and the ${ }^{13} \mathrm{C}$-NMR resonance at $\delta_{\mathrm{C}} 215.5$ also indicated the presence of a ketone group, and a quaternary carbon atom $\left(\delta_{\mathrm{C}} 76.5\right)$ with a hydroxyl function was observed in the ${ }^{13} \mathrm{C}$-NMR spectrum instead of the methine carbon which was seen in that of 2. Therefore one of the hydrogens on C-5 and C-6 in 2 must be replaced by a hydroxyl group. Since the axial proton on C-4 appeared as a triplet $(J=13 \mathrm{~Hz})$, the hydroxyl group was placed at the C-6 position. The lowfield shifts of the axial protons on $\mathrm{C}-2\left(\delta_{\mathrm{H}} 2.88\right.$ from 2.38$)$ and $\mathrm{C}-4\left(\delta_{\mathrm{H}} 2.46\right.$ from 2.22) from those of 2 due to 1,3-diaxial interactions indicated that the hydroxyl group at the C-6 position was in the axial

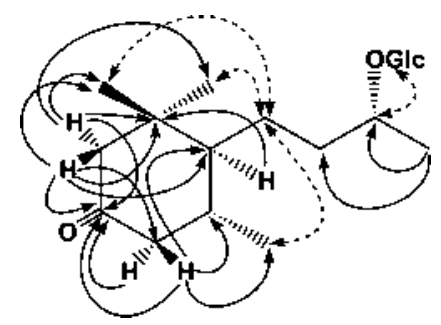

Fig. 2. Correlations in HMBC and Phase-Sensitive NOESY Spectra

Solid lines show selected HMBC correlations. Arrowheads denote carbon atoms and arrow tails proton atoms in the HMBC spectrum. Dotted lines denote phase-sensitive NOESY correlations.

Table 1. ${ }^{13}$ C-NMR Data for Ampelopsisionoside (1), Alangionoside J (5), Linarionoside A (7), Myrsinionosides A—E (2 — 4, 6, 8), and Aglycones (5a8a).

\begin{tabular}{|c|c|c|c|c|c|c|c|c|c|c|}
\hline & 1 & 2 & 3 & 4 & 5 & $5 \mathbf{a}(=6 \mathbf{a})$ & 6 & 7 & 8 & $\mathbf{8 a}(=7 \mathbf{a})$ \\
\hline 1 & 44.0 & 40.4 & 45.1 & 36.8 & 36.8 & 36.8 & 36.8 & 38.8 & 38.8 & 38.8 \\
\hline 2 & 46.2 & 57.2 & 54.0 & 48.8 & 48.8 & 51.9 & 51.9 & 47.5 & 47.6 & 49.8 \\
\hline 3 & 214.9 & 214.5 & 215.5 & 75.7 & 75.7 & 67.4 & 67.4 & 73.3 & 73.7 & 65.8 \\
\hline 4 & 52.5 & 50.9 & 47.0 & 44.8 & 44.8 & 46.6 & 46.5 & 39.8 & 39.9 & 43.0 \\
\hline 5 & 37.8 & 37.7 & 38.0 & 35.2 & 35.1 & 35.0 & 35.0 & 125.1 & 125.1 & 125.5 \\
\hline 6 & 78.1 & 53.6 & 76.5 & 54.2 & 54.2 & 54.3 & 54.3 & 138.5 & 138.6 & 138.3 \\
\hline 7 & 135.0 & 26.0 & 32.0 & 26.3 & 26.4 & 26.3 & 26.0 & 25.6 & 25.6 & 25.6 \\
\hline 8 & 134.0 & 40.5 & 32.2 & 42.6 & 42.7 & 42.7 & 40.7 & 40.8 & 40.7 & 40.8 \\
\hline 9 & 77.8 & 75.9 & 76.5 & 69.0 & 69.2 & 69.2 & 76.1 & 69.2 & 69.2 & 69.3 \\
\hline 10 & 21.5 & 19.8 & 20.0 & 23.5 & 23.4 & 23.4 & 19.7 & 23.3 & 23.3 & 23.3 \\
\hline 11 & 21.0 & 21.1 & 25.5 & 21.3 & 21.3 & 21.4 & 21.4 & 28.8 & 29.0 & 28.9 \\
\hline 12 & 25.4 & 30.3 & 25.2 & 31.3 & 31.3 & 31.4 & 31.4 & 30.3 & 30.3 & 30.4 \\
\hline 13 & 16.5 & 21.5 & 16.5 & 21.5 & 21.5 & 21.5 & 21.4 & 20.1 & 20.1 & 20.0 \\
\hline $1^{\prime}$ & 102.7 & 102.2 & 102.2 & 102.7 & 102.7 & & 102.2 & 102.3 & 102.6 & \\
\hline $2^{\prime}$ & 75.4 & 75.2 & 75.2 & 75.2 & 75.2 & & 75.2 & 75.2 & 75.2 & \\
\hline $3^{\prime}$ & 78.2 & 78.2 & 78.3 & 78.1 & 78.1 & & 78.2 & 78.2 & 78.1 & \\
\hline $4^{\prime}$ & 71.6 & 71.7 & 71.9 & 71.8 & 71.8 & & 71.9 & 71.7 & 71.7 & \\
\hline $5^{\prime}$ & 78.0 & 77.9 & 77.9 & 77.9 & 77.9 & & 77.8 & 77.9 & 76.8 & \\
\hline $6^{\prime}$ & 62.7 & 63.0 & 62.9 & 62.9 & 62.9 & & 63.0 & 62.8 & 68.6 & \\
\hline $1^{\prime \prime}$ & & & & & & & & & 110.9 & \\
\hline $2^{\prime \prime}$ & & & & & & & & & 78.1 & \\
\hline $3^{\prime \prime}$ & & & & & & & & & 80.6 & \\
\hline $4^{\prime \prime}$ & & & & & & & & & 75.1 & \\
\hline $5^{\prime \prime}$ & & & & & & & & & 65.8 & \\
\hline
\end{tabular}


orientation, and the CD spectrum also showed a positive Cotton effect at $281 \mathrm{~nm}([\theta]+334)$. Therefore the structure of $\mathbf{3}$ was elucidated to be $(5 R, 6 R, 9 R)$-megastigman-3-on-6,9-diol 9-O- $\beta$-D-glucopyranoside, namely dihydroampelopsisionioside.

Compounds 4 (myrsinionoside $\mathrm{C}$, minor) and $\mathbf{5}$ (major) were separated after exhaustive isolation work by repeated preparative HPLC. Although they exhibit different retention times on HPLC, their NMR spectroscopic data were essentially superimposable (see Table 1), and they were not distinguishable from those of alangionoside $\mathrm{J}[(3 S, 5 R, 6 S, 9 R)$ megastigman-3,9-diol 3-O- $\beta$-D-glucopyranoside], isolated from Alangium premnifolium. ${ }^{9)}$ Since compounds $\mathbf{4}$ and $\mathbf{5}$, and alangionoside $\mathrm{J}$ commonly bear a sugar unit on the hydroxyl group at the 3-position, the absolute configurations of their ring systems must be the same. This evidence indicated that compounds $\mathbf{4}$ and $\mathbf{5}$ could be different as to the absolute configuration of the 9-position. To determine the absolute configuration of the 9-position, compound 5 was enzymatically hydrolyzed and that of the aglycone was analyzed by a modified Mosher's method (Fig. 3). ${ }^{10)}$ As a result, compound 5 was identified as alangionoside J, while the structure of compound 4 was then elucidated to be $(3 S, 5 R, 6 S, 9 S)$ megastigman-3,9-diol 3-O- $\beta$-D-glucopyranoside, and the compound was named myrsinionoside $\mathrm{C}$.

Myrsinionoside D (6), $[\alpha]_{\mathrm{D}}-28.6^{\circ}$, was isolated as an amorphous powder and its elemental composition, $\mathrm{C}_{19} \mathrm{H}_{36} \mathrm{O}_{7}$, was found to be the same as those of alangionoside $\mathrm{J}(\mathbf{5})$ and myrsinionoside $\mathrm{C}(4)$. The ${ }^{1} \mathrm{H}$ - and ${ }^{13} \mathrm{C}-\mathrm{NMR}$ spectra, including ${ }^{1} \mathrm{H}-{ }^{1} \mathrm{H}$ COSY, HSQC, and $\mathrm{HMBC}$ spectra, of the aglycone portion were essentially superimposable with those of dihydroalangionoside I $[(3 S, 5 R, 6 S, 9 R)$-megastigman-3,9-diol $9-O-\beta$-D- $\left(6^{\prime}-O-\beta\right.$-D-apiofuranosyl)glucopyranoside] catalytically derived from the corresponding 7-ene (alangionoside I). ${ }^{9)}$ Therefore, $\mathbf{6}$ was expected to be a positional isomer of 5 in the position of the sugar linkage. The absolute stereochemistry of the ring system is most probably the same as that of $\mathbf{4}$ and $\mathbf{5}$. However, in this class of compounds, the stereochemistry at the side chain does not affect the NMR spectral behavior of the ring system, even when the aglycones exhibit diastereogenic and enantiomeric relations. Thus the stereochemistry of the ring system was similarly determined using the modified Mosher's method (Fig. 3; $\Delta \delta S-\delta R$ values are in parentheses) to be the same as that of 4 and $\mathbf{5}$, as shown in Fig. 1.

Compounds $\mathbf{7}$ and $\mathbf{8}$ were isolated as amorphous powders and spectroscopic analyses revealed that both have the common megastigmane-type aglycone, megastigman-5-en-3,9diol. The sugar moiety of 7 was assigned to be $\beta$-glucopyranose, whereas that of $\mathbf{8}$ was expected to be composed of two sugar units, such as terminal $\beta$-D-apiofuranose and 6-O-glycosylated $\beta$-D-glucopyranose, ${ }^{9}{ }^{9}$ from the negative-ion HRFAB-MS $\left(\mathrm{C}_{24} \mathrm{H}_{42} \mathrm{O}_{11}\right)$ spectrum, and the two anomeric protons and carbons $\left[\delta_{\mathrm{H}} 4.40(\mathrm{~J}=8 \mathrm{~Hz})\right.$ on $\delta_{\mathrm{C}} 102.6$ and $\delta_{\mathrm{H}} 4.98$ $(J=2 \mathrm{~Hz})$ on $\left.\delta_{\mathrm{C}} 110.9\right]$ in the one- and two-dimensional NMR spectra. Therefore compound 7 was identified as linarionoside A, which has been isolated from Linaria japon$i c a{ }^{11)}$ Thus compound 8 was $6^{\prime}-O-\beta$-D-apiofuranosyl linarinoside $\mathrm{A}$, and we named it myrsinionoside $\mathrm{E}$. To determine the absolute configuration of the 9-position of $\mathbf{8}$, the same procedure as that used for the aforementioned compounds

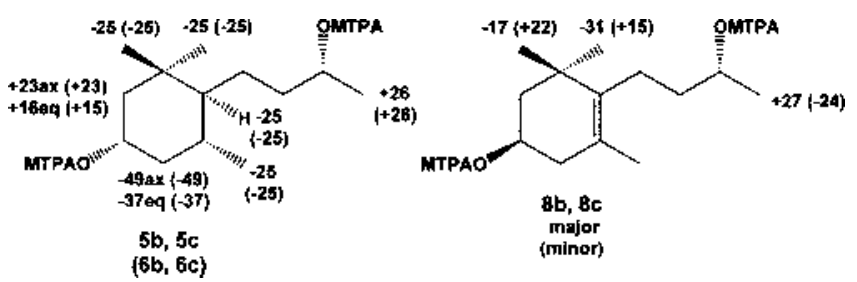

Fig. 3. Results of the Modified Mosher's Method for $\mathbf{5 b}$ and $\mathbf{5 c}, \mathbf{6} \mathbf{b}$ and $6 c$, and $8 b$ and $8 c$

The $\Delta \delta$ values are in $\mathrm{Hz}(\delta S-\delta R, 400 \mathrm{MHz})$. The figures in parentheses in the structure on the left are the results for $\mathbf{6 b}$ and $\mathbf{6 c}$. The figures in parentheses for $\mathbf{8 b}$ and $\mathbf{8 c}$ are for the minor stereoisomer.

was applied. However, the ${ }^{1} \mathrm{H}-\mathrm{NMR}$ spectra of the $(R)$ - and $(S)$-MTPA diesters $(\mathbf{8 b}, \mathbf{c})$ of the aglycone $(\mathbf{8 a})$ of $\mathbf{8}$ showed highly complex signals. From the results obtained with the modified Mosher's method applied to both the major peaks and minor peaks, it was concluded that myrsinionoside $\mathrm{E}$ was a mixture of $9 S$ - and $9 R$-derivatives in a ratio of nearly $1: 2$ (Fig. 3). Finally, the structure of myrsinionoside E (8) was characterized as a mixture of $(3 S, 9 R)$ - and $(3 S, 9 S)$-megastigman-5-en-3,9-diol 3-O- $\beta$-D-(6'-O- $\beta$-D-apiofuranosyl)glucopyranoside, as shown in Fig. 1. For this reason, the same assumption must be applicable to compound 7. Linarionoside A (7) isolated from this plant was most probably a mixture of $9 R$ - and $9 S$-diastereomers.

\section{Experimental}

The melting point was determined with a Yanagimoto micro melting point apparatus and is uncorrected. Optical rotations were measured on a Union Giken PM-101 digital polarimeter. FT-IR spectra were recorded on a Horiba FT-710 spectrophotometer. ${ }^{1} \mathrm{H}$ - and ${ }^{13} \mathrm{C}$-NMR spectra were recorded on a JEOL $\alpha-400$ spectrometer ( 400 and $100 \mathrm{MHz}$, respectively) with tetramethylsilane (TMS) as internal standard. HR-FAB-MS analyses were carried out on a JEOL SX-102 mass spectrometer with PEG-400 as the calibration matrix. CD spectra were measured on a JASCO J-720 spectropolarimeter. Silica gel and reversed-phase octadecyl silica (ODS) gel open column chromatographies (RPCC) were performed on silica gel 60 (Merck, 70-230 mesh) and Cosmosil $75 \mathrm{C}_{18}$-OPN (Nacalai Tesque Co., Ltd., Kyoto, Japan) $\left[\Phi=50 \mathrm{~mm}, \mathrm{~L}=25 \mathrm{~cm}\right.$, linear gradient: $\mathrm{MeOH}-\mathrm{H}_{2} \mathrm{O}(1: 9,1.51) \rightarrow(7: 3$, $1.51)$, fractions of $10 \mathrm{~g}$ being collected. The droplet counter-current chromatograph (DCCC) (Tokyo Rikakikai, Tokyo, Japan) was equipped with 500 glass columns ( $\Phi=2 \mathrm{~mm}, \mathrm{~L}=40 \mathrm{~cm})$, and the lower and upper layers of the solvent, $\mathrm{CHCl}_{3}-\mathrm{MeOH}-\mathrm{H}_{2} \mathrm{O}-n$-PrOH $(9: 12: 8: 2)$, were used for the stationary and mobile phases, respectively. Five-gram fractions were collected and numbered according to the order of elution of the mobile phase. HPLC was performed on an ODS column [ $\Phi=20$ or $6 \mathrm{~mm}, \mathrm{~L}=250 \mathrm{~mm}$; Inertsil, GL Science Co., Ltd. (Tokyo, Japan)] with UV at 254 or $210 \mathrm{~nm}$ and refractive index monitors. Precoated Silica gel 60 F254 TLC plates (Merck, $0.25 \mathrm{~mm}$ in thickness) were used for identification and preparative purification. Emulsin, hesperidinase and methyl $\beta$-D-xylopyranoside were purchased from Sigma Chem. Co. (St. Louis, MO, U.S.A.), and $(R)-(+)-$ and $(S)-(-)-$ $\alpha$-methoxy- $\alpha$-trifluoromethylphenylacetic acids (MPTA) were from Nacalai Tesque Co., Ltd.

Plant Material Leaves of Myrsine seguinii were collected in Okinawa prefecture in 1992 and the plant material was identified by Anki Takushi of the Okinawa Prefectural Experimental Station of Forestry, to whom the authors are very grateful. A voucher specimen was deposited in the Herbarium of the Institute of Pharmaceutical Sciences, Hiroshima University Faculty of Medicine (No. 92-MS-Okinawa-0727).

Extraction and Isolation Dried leaves $(5.95 \mathrm{~kg})$ of $M$. seguinii were extracted with $\mathrm{MeOH}(401 \times 3)$ and then the $\mathrm{MeOH}$ extract was concentrated to 21 . The concentrated $\mathrm{MeOH}$ layer was washed with $n$-hexane $(11 \times 2, n$ hexane-soluble fraction, $61.1 \mathrm{~g}$ ), and the $\mathrm{MeOH}$ was concentrated to yield a viscous gummy material. The latter was suspended in $\mathrm{H}_{2} \mathrm{O}(31)$, and then extracted with EtOAc (31) and $n$-BuOH (31) successively to give EtOAc- and $n$-BuOH-soluble fractions ( $195 \mathrm{~g}$ and $200 \mathrm{~g}$, respectively). The remaining $\mathrm{H}_{2} \mathrm{O}$ layer was concentrated to furnish an $\mathrm{H}_{2} \mathrm{O}$-soluble fraction $(380 \mathrm{~g})$. 
A portion $(50.0 \mathrm{~g})$ of the $n$-BuOH-soluble fraction was separated first by column chromatography $(\mathrm{CC})$ on a highly porous synthetic resin, Diaion HP-20 $(\Phi=5.0 \mathrm{~cm}, \mathrm{~L}=60 \mathrm{~cm})$ (Mitsubishi Chemical Co., Ltd., Tokyo, Japan), with $\mathrm{MeOH}-\mathrm{H}_{2} \mathrm{O}[(1: 4,3.51),(2: 3,31),(3: 2,31)$ and $(4: 1,31)$, and $\mathrm{MeOH}(31)$ ], and $500 \mathrm{ml}$ fractions were collected. The residue (14.8 $\mathrm{g}$ in fractions 9-15) of the $40 \% \mathrm{MeOH}$ eluate obtained on HP-20 CC was subjected to silica gel $(200 \mathrm{~g}) \mathrm{CC}$ with $\mathrm{CHCl}_{3}(21)$ and $\mathrm{CHCl}_{3}-\mathrm{MeOH}(99: 1$, $31),(97: 3,31),(19: 1,31),(37: 3,31),(9: 1,31),(17: 3,31)$, and $(4: 1,31)$, fractions of $500 \mathrm{ml}$ being collected. The residue $(761 \mathrm{mg}$ in fractions $41-$ $54)$ of the $7.5 \% \mathrm{MeOH}$ eluate was then subjected to RPCC. The residue (183 mg in fractions 99-111) was separated by DCCC to give $101 \mathrm{mg}$ of ampelopsisionoside (1). The residue (66 $\mathrm{mg}$ in fractions $112-120$ ) was separated by DCCC and its residue (18 $\mathrm{mg}$ in fractions $75-85$ ) was purified by prep. HPLC ( $\left.\mathrm{MeOH}-\mathrm{H}_{2} \mathrm{O}, 35: 65\right)$ to give $8 \mathrm{mg}$ of myrsinionoside $\mathrm{B}(3)$. The residue ( $86 \mathrm{mg}$ in fractions $141-150$ ) was subjected to DCCC and then to prep. HPLC ( $\left.\mathrm{MeOH}-\mathrm{H}_{2} \mathrm{O}, 2: 3\right)$ to give $8 \mathrm{mg}$ of linarionoside A (7). From the residue (64 $\mathrm{mg}$ in fractions $151-161)$, myrsinionoside $\mathrm{C}(4,3 \mathrm{mg})$ and alangionoside $\mathrm{J}(\mathbf{5}, 15 \mathrm{mg})$ were isolated by exhaustive HPLC separation $\left[\mathrm{MeOH}-\mathrm{H}_{2} \mathrm{O}, 2: 3\right.$; Inertsil $(\Phi=6 \mathrm{~mm}, \mathrm{~L}=250 \mathrm{~mm})$; flow rate, $1.6 \mathrm{ml} / \mathrm{min}$; $t_{\mathrm{R}}: 20.0 \mathrm{~min}$ and $21.0 \mathrm{~min}$, respectively]. From the residue $(39 \mathrm{mg}$ in fractions $162-170)$, myrsinionoside D $(\mathbf{6}, 24 \mathrm{mg})$ was isolated by DCCC. From the residue $(1.18 \mathrm{~g}$ in fractions $70-80)$ of the $15-20 \% \mathrm{MeOH}$ eluate obtained on silica gel CC, $12 \mathrm{mg}$ of myrsinionoside $\mathrm{E}(\mathbf{8})$ was isolated by similar chromatographic separation.

From the residue $(3.25 \mathrm{~g}$ in fractions $16-19)$ of the $60 \% \mathrm{MeOH}$ eluate obtained on HP-20 CC, myrsinionoside A (2, 23 mg) was isolated similarly by silica gel CC, RPCC and DCCC.

Known Compounds Isolated Compound 1: Amorphous powder; $[\alpha]_{\mathrm{D}}^{24}$ ca. $0^{\circ}(c=0.71, \mathrm{MeOH}) ; \mathrm{CD}[\theta](\mathrm{nm}):+792(277)\left(c=5.51 \times 10^{-3} \mathrm{M}\right){ }^{6 a}$ ${ }^{13} \mathrm{C}-\mathrm{NMR}\left(\mathrm{CD}_{3} \mathrm{OD}\right)$ : Table 1. Compound 5: $[\alpha]_{\mathrm{D}}^{18}-41.6^{\circ} \quad(c=0.67$, $\mathrm{MeOH}) ;{ }^{13} \mathrm{C}-\mathrm{NMR}\left(\mathrm{CD}_{3} \mathrm{OD}\right)$ : Table 1. Compound 7: Amorphous powder; $[\alpha]_{\mathrm{D}}^{18}-60.8^{\circ}(c=0.49, \mathrm{MeOH}) ;{ }^{11}{ }^{13} \mathrm{C}-\mathrm{NMR}\left(\mathrm{CD}_{3} \mathrm{OD}\right)$ : Table 1.

Compound 2: Amorphous powder; $[\alpha]_{\mathrm{D}}^{24}-13.8^{\circ}(c=1.30, \mathrm{MeOH})$; IR $v_{\max }(\mathrm{KBr}) \mathrm{cm}^{-1}: 3429,2963,2928,2878,1702,1377,1161,1078,1035$; ${ }^{1} \mathrm{H}-\mathrm{NMR}\left(\mathrm{CD}_{3} \mathrm{OD}\right) \delta: 0.761$ (3H, s, $\left.\mathrm{H}_{3}-11 \mathrm{ax}\right), 1.06\left(3 \mathrm{H}, \mathrm{s}, \mathrm{H}_{3}-12 \mathrm{eq}\right), 1.09$ $\left(3 \mathrm{H}, \mathrm{d}, J=6 \mathrm{~Hz}, \mathrm{H}_{3}-13\right), 1.20\left(3 \mathrm{H}, \mathrm{d}, J=6 \mathrm{~Hz}, \mathrm{H}_{3}-10\right), 1.14(1 \mathrm{H}, \mathrm{m}, \mathrm{H}-6)$, $1.15(1 \mathrm{H}, \mathrm{m}, \mathrm{H}-7 \mathrm{a}), 1.67(1 \mathrm{H}, \mathrm{m}, \mathrm{H}-7 \mathrm{~b}), 1.68\left(2 \mathrm{H}, \mathrm{m}, \mathrm{H}_{2}-8\right), 1.78(1 \mathrm{H}, \mathrm{m}$, H-5), 1.96 (1H, dd, $J=13,2 \mathrm{~Hz}, \mathrm{H}-2 \mathrm{eq}), 2.14$ (1H, t, $J=14 \mathrm{~Hz}, \mathrm{H}-4 \mathrm{ax}), 2.22$ $(1 \mathrm{H}$, ddd, $J=14,5,2 \mathrm{~Hz}, \mathrm{H}-4 \mathrm{eq}), 2.38(1 \mathrm{H}, \mathrm{d}, J=13 \mathrm{~Hz}, \mathrm{H}-2 \mathrm{ax}), 3.15(1 \mathrm{H}$, dd, $\left.J=9,8 \mathrm{~Hz}, \mathrm{H}-2^{\prime}\right), 3.26\left(1 \mathrm{H}, \mathrm{m}, \mathrm{H}-5^{\prime}\right), 3.28\left(1 \mathrm{H}, \mathrm{t}, J=9 \mathrm{~Hz}, \mathrm{H}-4^{\prime}\right), 3.36$ $\left(1 \mathrm{H}, \mathrm{t}, J=9 \mathrm{~Hz}, \mathrm{H}-3^{\prime}\right), 3.66\left(1 \mathrm{H}, \mathrm{dd}, J=12,6 \mathrm{~Hz}, \mathrm{H}-6^{\prime} \mathrm{a}\right), 3.86(1 \mathrm{H}, \mathrm{dd}$, $\left.J=12,2 \mathrm{~Hz}, \mathrm{H}-6^{\prime} \mathrm{b}\right), 3.87(1 \mathrm{H}$, sextet, $J=6 \mathrm{~Hz}, \mathrm{H}-9), 4.34(1 \mathrm{H}, \mathrm{d}, J=8 \mathrm{~Hz}$, $\left.\mathrm{H}-1^{\prime}\right) ;{ }^{13} \mathrm{C}-\mathrm{NMR}\left(\mathrm{CD}_{3} \mathrm{OD}\right)$ : Table $1 ; \mathrm{CD}[\theta](\mathrm{nm}):+871$ (282) $(c=$ $5.21 \times 10^{-3} \mathrm{M}, \mathrm{MeOH}$ ); HR-FAB-MS (negative-ion mode) $\mathrm{m} / \mathrm{z}: 373.2228$ $[\mathrm{M}-\mathrm{H}]^{-}\left(\right.$Calcd for $\left.\mathrm{C}_{19} \mathrm{H}_{33} \mathrm{O}_{7}: 373.2226\right)$.

Compound 3: Amorphous powder, $[\alpha]_{\mathrm{D}}^{24}-3.0^{\circ}(c=0.41, \mathrm{MeOH})$; IR $v_{\max }$ (KBr) cm ${ }^{-1}: 3429,2967,2931,2881,1698,1379,1078,1034 ;{ }^{1} \mathrm{H}-\mathrm{NMR}$ $\left(\mathrm{CD}_{3} \mathrm{OD}\right) \delta: 0.927\left(3 \mathrm{H}, \mathrm{s}, \mathrm{H}_{3}-11 \mathrm{ax}\right), 1.08\left(3 \mathrm{H}, \mathrm{s}, \mathrm{H}_{3}-12 \mathrm{eq}\right), 1.02(3 \mathrm{H}, \mathrm{d}$, $\left.J=6 \mathrm{~Hz}, \mathrm{H}_{3}-13\right), 1.20\left(3 \mathrm{H}, \mathrm{d}, J=6 \mathrm{~Hz}, \mathrm{H}_{3}-10\right), 1.66\left(2 \mathrm{H}, \mathrm{m}, \mathrm{H}_{2}-7\right), 1.74(1 \mathrm{H}$, dd, $J=13,2 \mathrm{~Hz}, \mathrm{H}-2 \mathrm{eq}), 1.75(1 \mathrm{H}$, ddd, $J=14,10,6 \mathrm{~Hz}, \mathrm{H}-7 \mathrm{a}), 1.88(1 \mathrm{H}$, ddd, $J=14,11,4 \mathrm{~Hz}, \mathrm{H}-7 \mathrm{~b}), 2.03$ (1H, ddd, $J=13,5,2 \mathrm{~Hz}, \mathrm{H}-4 \mathrm{eq}), 2.23(1 \mathrm{H}$, dqd, $J=13,6,5 \mathrm{~Hz}, \mathrm{H}-5), 2.46(1 \mathrm{H}, \mathrm{t}, J=13 \mathrm{~Hz}, \mathrm{H}-4 \mathrm{ax}), 2.88(1 \mathrm{H}, \mathrm{d}$, $J=13 \mathrm{~Hz}, \mathrm{H}-2 \mathrm{ax}), 3.15\left(1 \mathrm{H}, \mathrm{dd}, J=9,8 \mathrm{~Hz}, \mathrm{H}-2^{\prime}\right), 3.57(1 \mathrm{H}$, sextet, $J=6 \mathrm{~Hz}$, H-9), 3.66 (1H, dd, $\left.J=12,6 \mathrm{~Hz}, \mathrm{H}-6^{\prime} \mathrm{a}\right), 3.86$ (1H, dd, $\left.J=12,2 \mathrm{~Hz}, \mathrm{H}-6^{\prime} \mathrm{b}\right)$, $4.33\left(1 \mathrm{H}, \mathrm{d}, J=8 \mathrm{~Hz}, \mathrm{H}-1^{\prime}\right) ;{ }^{13} \mathrm{C}-\mathrm{NMR}\left(\mathrm{CD}_{3} \mathrm{OD}\right)$ : Table 1 ; $\mathrm{CD}[\theta](\mathrm{nm})$ : +439 (246), +334 (281) $\left(c=3.13 \times 10^{-3} \mathrm{M}\right)$; HR-FAB-MS (negative-ion mode) $m / z: 389.2182[\mathrm{M}-\mathrm{H}]^{-}\left(\right.$Calcd for $\left.\mathrm{C}_{19} \mathrm{H}_{33} \mathrm{O}_{8}: 389.2175\right)$.

Compound 4: Amorphous powder, ${ }^{1} \mathrm{H}-\mathrm{NMR}\left(\mathrm{CD}_{3} \mathrm{OD}\right) \delta$ : $0.548(1 \mathrm{H}$, ddd, $J=11,5,2 \mathrm{~Hz}, \mathrm{H}-6), 0.831$ (3H, s, $\left.\mathrm{H}_{3}-11 \mathrm{ax}\right), 0.962$ (3H, s, $\left.\mathrm{H}_{3}-12 \mathrm{eq}\right), 0.981$ $\left(3 \mathrm{H}, \mathrm{d}, J=6 \mathrm{~Hz}, \mathrm{H}_{3}-13\right), 1.06(1 \mathrm{H}, \mathrm{q}, J=12 \mathrm{~Hz}, \mathrm{H}-4 \mathrm{ax}), 1.14(3 \mathrm{H}, \mathrm{d}, J=6 \mathrm{~Hz}$, $\left.\mathrm{H}_{3}-10\right), 1.15(1 \mathrm{H}, \mathrm{t}, J=14 \mathrm{~Hz}, \mathrm{H}-2 \mathrm{ax}), 1.32-1.62(4 \mathrm{H}, \mathrm{m}, \mathrm{H}-5,7 \mathrm{~b}, 8 \mathrm{a}, 8 \mathrm{~b})$, $1.80(1 \mathrm{H}, \mathrm{ddd}, J=14,4,2 \mathrm{~Hz}, \mathrm{H}-2 \mathrm{eq}), 2.02(1 \mathrm{H}, \mathrm{m}, \mathrm{H}-4 \mathrm{eq}), 3.11(1 \mathrm{H}, \mathrm{dd}$, $\left.J=9,8 \mathrm{~Hz}, \mathrm{H}-2^{\prime}\right), 3.65\left(1 \mathrm{H}, \mathrm{dd}, J=12,6 \mathrm{~Hz}, \mathrm{H}-6^{\prime} \mathrm{a}\right), 3.66(1 \mathrm{H}, \mathrm{m}, \mathrm{H}-3), 3.84$ $(1 \mathrm{H}$, sextet, $J=6 \mathrm{~Hz}, \mathrm{H}-9), 3.85\left(1 \mathrm{H}, \mathrm{dd}, J=12,2 \mathrm{~Hz}, \mathrm{H}-6^{\prime} \mathrm{b}\right), 4.33(1 \mathrm{H}, \mathrm{d}$, $\left.J=8 \mathrm{~Hz}, \mathrm{H}-1^{\prime}\right) ;{ }^{13} \mathrm{C}-\mathrm{NMR}\left(\mathrm{CD}_{3} \mathrm{OD}\right)$ : see Table 1; HR-FAB-MS (negative-ion mode) $m / z: 375.2399[\mathrm{M}-\mathrm{H}]^{-}\left(\right.$Calcd for $\mathrm{C}_{19} \mathrm{H}_{35} \mathrm{O}_{7}: 375.2383$ ).

Compound 6: Amorphous powder, $[\alpha]_{\mathrm{D}}^{24}-28.6^{\circ}(c=1.40, \mathrm{MeOH})$; IR $v_{\max }(\mathrm{KBr}) \mathrm{cm}^{-1}: 3396,2966,2924,2875,1471,1372,1161,1078,1024$; ${ }^{1} \mathrm{H}-\mathrm{NMR}\left(\mathrm{CD}_{3} \mathrm{OD}\right) \delta: 0.523(1 \mathrm{H}, \mathrm{ddd}, J=1,4,10 \mathrm{~Hz}, \mathrm{H}-6), 0.823(3 \mathrm{H}, \mathrm{s}$, $\left.\mathrm{H}_{3}-11 \mathrm{ax}\right), 0.900(1 \mathrm{H}, \mathrm{q}, J=12 \mathrm{~Hz}, \mathrm{H}-4 \mathrm{ax}), 0.945\left(3 \mathrm{H}, \mathrm{s}, \mathrm{H}_{3}-12 \mathrm{eq}\right), 0.975$ $\left(3 \mathrm{H}, \mathrm{d}, J=6 \mathrm{~Hz}, \mathrm{H}_{3}-13\right), 1.08(1 \mathrm{H}, \mathrm{t}, J=12 \mathrm{H}, \mathrm{H}-2 \mathrm{ax}), c a .1 .08(1 \mathrm{H}, \mathrm{m}, \mathrm{H}-$ 7a), $1.17\left(3 \mathrm{H}, \mathrm{d}, J=6 \mathrm{~Hz}, \mathrm{H}_{3}-10\right), 1.44(1 \mathrm{H}, \mathrm{m}, \mathrm{H}-5), 1.52-1.60(3 \mathrm{H}, \mathrm{m}, \mathrm{H}-$ 7b, -8a, -8b), 1.63 (1H, ddd, $J=13,4,2 \mathrm{~Hz}, \mathrm{H}-2 \mathrm{eq}), 1.88$ (1H, m, H-4eq), $3.14\left(1 \mathrm{H}, \mathrm{dd}, J=9,8 \mathrm{~Hz}, \mathrm{H}-2^{\prime}\right), 3.66\left(1 \mathrm{H}, \mathrm{dd}, J=12,6 \mathrm{~Hz}, \mathrm{H}-6{ }^{\prime} \mathrm{a}\right), 3.69(1 \mathrm{H}$, tt, $J=12,4 \mathrm{~Hz}, \mathrm{H}-3), 3.84(1 \mathrm{H}$, sextet, $J=6 \mathrm{~Hz}, \mathrm{H}-9), 3.85(1 \mathrm{H}, \mathrm{dd}, J=12$, $\left.2 \mathrm{~Hz}, \mathrm{H}-6{ }^{\prime} \mathrm{b}\right), 4.33$ (1H, d, $\left.J=8 \mathrm{~Hz}, \mathrm{H}-1^{\prime}\right) ;{ }^{13} \mathrm{C}-\mathrm{NMR}\left(\mathrm{CD}_{3} \mathrm{OD}\right)$ : Table 1; HRFAB-MS (negative-ion mode) $\mathrm{m} / z: 375.2407[\mathrm{M}-\mathrm{H}]^{-}$(Calcd for $\mathrm{C}_{19} \mathrm{H}_{36} \mathrm{O}_{7}$ : 375.2383)

Compound 8: Amorphous powder, $[\alpha]_{\mathrm{D}}^{18}-76.4^{\circ}(c=0.72, \mathrm{MeOH})$; IR $v_{\max }(\mathrm{KBr}) \mathrm{cm}^{-1}: 3399,2962,2928,2879,1457,1368,1165,1074,1051$, 1016; ${ }^{1} \mathrm{H}-\mathrm{NMR}\left(\mathrm{CD}_{3} \mathrm{OD}\right) \delta: 1.06\left(6 \mathrm{H}, \mathrm{s}, \mathrm{H}_{3}-12 \mathrm{eq}\right), 1.07$ (3H, s, $\left.\mathrm{H}_{3}-11 \mathrm{ax}\right)$, $1.16\left(3 \mathrm{H}, \mathrm{d}, J=6 \mathrm{~Hz}, \mathrm{H}_{3}-10\right), 1.45-1.51(2 \mathrm{H}, \mathrm{m}, \mathrm{H}-8 \mathrm{a},-8 \mathrm{~b}), 1.48(1 \mathrm{H}, \mathrm{t}$, $J=12 \mathrm{~Hz}, \mathrm{H}-2 \mathrm{ax}), 1.64\left(3 \mathrm{H}, \mathrm{s}, \mathrm{H}_{3}-13\right), 1.85(1 \mathrm{H}, \mathrm{ddd}, J=12,4,2 \mathrm{~Hz}, \mathrm{H}-$ $2 \mathrm{eq}), 1.90(1 \mathrm{H}, \mathrm{d} t, J=11,6 \mathrm{~Hz}, \mathrm{H}-7 \mathrm{a}), 2.01(1 \mathrm{H}, \mathrm{br} \mathrm{dd}, J=16,9 \mathrm{~Hz}, \mathrm{H}-4 \mathrm{ax})$, $2.20(1 \mathrm{H}, \mathrm{d} t, J=11,6 \mathrm{~Hz}, \mathrm{H}-7 \mathrm{~b}), 2.32(1 \mathrm{H}, \mathrm{br} \mathrm{dd}, J=16,4 \mathrm{~Hz}, \mathrm{H}-4 \mathrm{eq}), 3.14$ $\left(1 \mathrm{H}, \mathrm{dd}, J=9,8 \mathrm{~Hz}, \mathrm{H}-2^{\prime}\right), 3.34\left(1 \mathrm{H}, \mathrm{t}, J=9 \mathrm{~Hz}, \mathrm{H}-3^{\prime}\right), 3.39$ (1H, ddd, $J=9$, $\left.6,2 \mathrm{~Hz}, \mathrm{H}-5^{\prime}\right), 3.57\left(2 \mathrm{H}, \mathrm{s}, \mathrm{H}_{2}-5^{\prime \prime}\right), 3.60\left(1 \mathrm{H}, \mathrm{dd}, J=12,6 \mathrm{~Hz}, \mathrm{H}-6^{\prime} \mathrm{a}\right), 3.70$ $(1 \mathrm{H}$, sextet, $J=6 \mathrm{~Hz}, \mathrm{H}-9), 3.76\left(1 \mathrm{H}, \mathrm{d}, J=10 \mathrm{~Hz}, \mathrm{H}-4{ }^{\prime \prime} \mathrm{a}\right), 3.88(1 \mathrm{H} . \mathrm{d}$, $\left.J=2 \mathrm{~Hz}, \mathrm{H}-2^{\prime \prime}\right), 3.96\left(1 \mathrm{H}, \mathrm{d}, J=10 \mathrm{~Hz}, \mathrm{H}-4^{\prime \prime} \mathrm{b}\right), 3.97(1 \mathrm{H}, \mathrm{dd}, J=12,2 \mathrm{~Hz}, \mathrm{H}-$ $\left.6^{\prime} \mathrm{b}\right), 4.00(1 \mathrm{H}, \mathrm{m}, \mathrm{H}-3), 4.40\left(1 \mathrm{H}, \mathrm{d}, J=8 \mathrm{~Hz}, \mathrm{H}-1^{\prime}\right), 4.98(1 \mathrm{H}, \mathrm{d}, J=2 \mathrm{~Hz}$, $\mathrm{H}-1 ") ;{ }^{13} \mathrm{C}-\mathrm{NMR}\left(\mathrm{CD}_{3} \mathrm{OD}\right)$ : Table 1; HR-FAB-MS (negative-ion mode) $\mathrm{m} / \mathrm{z}$ : $505.2654[\mathrm{M}-\mathrm{H}]^{-}$(Calcd for $\mathrm{C}_{24} \mathrm{H}_{41} \mathrm{O}_{11}: 505.2649$ ).

Acetylation of 2 to 2a About $2 \mathrm{mg}$ of 2 was acetylated with $100 \mu \mathrm{l}$ each of acetic anhydride and pyridine. After $4 \mathrm{~h}$ at $25^{\circ} \mathrm{C}$, the reagents were evaporated to give the tetraacetate (2a). Myrsinionoside tetraacetate (2a): Colorless crystals $(\mathrm{EtOH}) ; \mathrm{mp} 112-115^{\circ} \mathrm{C} ;{ }^{1} \mathrm{H}-\mathrm{NMR}\left(\mathrm{CDCl}_{3}\right) \delta: 0.764(3 \mathrm{H}, \mathrm{s}$, $\left.\mathrm{H}_{3}-11 \mathrm{ax}\right), 1.035\left(3 \mathrm{H}, \mathrm{s}, \mathrm{H}_{3}-12 \mathrm{eq}\right), 1.038\left(3 \mathrm{H}, \mathrm{d}, J=7 \mathrm{~Hz}, \mathrm{H}_{3}-13\right), 1.13(3 \mathrm{H}$, d, $\left.J=6 \mathrm{~Hz}, \mathrm{H}_{3}-10\right), 1.50-1.65(3 \mathrm{H}, \mathrm{m}, \mathrm{H}-7 \mathrm{~b},-8 \mathrm{a},-8 \mathrm{~b}), 1.76(1 \mathrm{H}, \mathrm{m}, \mathrm{H}-5)$, $2.25(1 \mathrm{H}, \mathrm{d}, J=14 \mathrm{~Hz}, \mathrm{H}-2 \mathrm{ax}), 2.29$ (1H, ddd, $J=14,4,2 \mathrm{~Hz}, \mathrm{H}-4 \mathrm{eq}), 3.67$ $\left(1 \mathrm{H}\right.$, ddd, $\left.J=9,5,3 \mathrm{~Hz}, \mathrm{H}-5^{\prime}\right), 3.72(1 \mathrm{H}, \mathrm{m}, \mathrm{H}-9), 4.13(1 \mathrm{H}, \mathrm{dd}, J=12,3 \mathrm{~Hz}$, H-6'a), 4.23 (1H, dd, $\left.J=12,5 \mathrm{~Hz}, \mathrm{H}-6^{\prime} \mathrm{b}\right), 4.55\left(1 \mathrm{H}, \mathrm{d}, J=8 \mathrm{~Hz}, \mathrm{H}-1^{\prime}\right), 4.94$ $\left(1 \mathrm{H}, \mathrm{dd}, J=9,8 \mathrm{~Hz}, \mathrm{H}-2^{\prime}\right), 5.08\left(1 \mathrm{H}, \mathrm{t}, J=9 \mathrm{~Hz}, \mathrm{H}-4^{\prime}\right), 5.21(1 \mathrm{H}, \mathrm{t}, J=9 \mathrm{~Hz}$, $\mathrm{H}-3^{\prime}$ ), other signals were overlapped by the methyl signals of the aglycone and acetyls; ${ }^{13} \mathrm{C}-\mathrm{NMR}\left(\mathrm{CDCl}_{3}\right) \delta: 19.6(\mathrm{C}-10), 20.59,20.62,20.64,20.67$, 20.73, $21.05\left(\mathrm{C}-11,-13, \mathrm{CH}_{3} \mathrm{CO}^{-} \times 4\right), 24.6(\mathrm{C}-7), 29.9(\mathrm{C}-12), 36.2(\mathrm{C}-5)$, 39.0 (C-8), 39.4 (C-1), 50.2 (C-4), 52.6 (C-6), 56.5 (C-2), 62.2 (C-6'), 68.7 $\left(\mathrm{C}-4^{\prime}\right), 71.68,71.72,73.0\left(\mathrm{C}-2^{\prime}, 3^{\prime}, 5^{\prime}\right), 76.1$ (C-9), 99.2 (C-1'), 169.2, 169.4, 170.3, $170.5\left(\mathrm{CH}_{3} \mathrm{CO}^{-} \times 4\right), 211.1$ (C-3); HR-FAB-MS (positive-ion mode, $m$-nitrobenzyl alcohol as the matrix) $m / z$ : $565.2641[\mathrm{M}+\mathrm{Na}]^{+}$ (+NaI) (Calcd for $\mathrm{C}_{27} \mathrm{H}_{42} \mathrm{O}_{11} \mathrm{Na}$ : 565.2625).

Enzymatic Hydrolysis of 2 Compound $2(c a .1 \mathrm{mg})$ was treated with $2 \mathrm{mg}$ of emulsin at $37^{\circ} \mathrm{C}$ in $200 \mu \mathrm{l}$ of $\mathrm{H}_{2} \mathrm{O}$. Liberation of glucose was traced by TLC analysis $\left(\mathrm{CHCl}_{3}-\mathrm{MeOH}-\mathrm{H}_{2} \mathrm{O}, 15: 6: 1, R f\right.$ values, $2: 0.51$, aglycone: 0.81 , and D-glucose: 0.12 ).

Enzymatic Hydrolysis of 5 to $\mathbf{5 a}$ Compound $\mathbf{5}(15.0 \mathrm{mg})$ was hydrolyzed with emulsin $(10 \mathrm{mg})$ in $2 \mathrm{ml}$ of $\mathrm{H}_{2} \mathrm{O}$ at $37^{\circ} \mathrm{C}$ for $12 \mathrm{~h}$. The reaction mixture was concentrated and then subjected to silica gel column $(20 \mathrm{~g}$, $\Phi=15 \mathrm{~mm}, \mathrm{~L}=20 \mathrm{~cm})$ chromatography with $\mathrm{CHCl}_{3}(100 \mathrm{ml}), \mathrm{CHCl}_{3}-\mathrm{MeOH}$ $(19: 1,100 \mathrm{ml}, 9: 1100 \mathrm{ml}, 17: 3,100 \mathrm{ml}, 7: 3,300 \mathrm{ml})$, and $10 \mathrm{ml}$ fractions were collected. The aglycone (5a) and D-glucose were recovered in fractions $40-46(6.2 \mathrm{mg}, 73 \%)$ and $41-49(3.5 \mathrm{mg}, 49 \%)$, respectively. Aglycone (5a): Amorphous powder; $[\alpha]_{\mathrm{D}}^{21}-15.0^{\circ}(c=0.41, \mathrm{MeOH}) ;{ }^{1} \mathrm{H}-\mathrm{NMR}$ $\left(\mathrm{CD}_{3} \mathrm{OD}\right) \delta: 0.529(1 \mathrm{H}, \mathrm{ddd}, J=11,5,3 \mathrm{~Hz}, \mathrm{H}-6), 0.831\left(3 \mathrm{H}, \mathrm{s}, \mathrm{H}_{3}-11 \mathrm{ax}\right)$, $0.905(1 \mathrm{H}, \mathrm{q}, J=12 \mathrm{~Hz}, \mathrm{H}-4 \mathrm{ax}), 0.950\left(3 \mathrm{H}, \mathrm{s}, \mathrm{H}_{3}-12 \mathrm{eq}\right), 0.972(3 \mathrm{H}, \mathrm{d}$, $\left.J=6 \mathrm{~Hz}, \mathrm{H}_{3}-13\right), 1.09(1 \mathrm{H}, \mathrm{t}, J=12 \mathrm{~Hz}, \mathrm{H}-2 \mathrm{ax}), 1.15\left(3 \mathrm{H}, \mathrm{d}, J=6 \mathrm{~Hz}, \mathrm{H}_{3}-10\right)$, $1.38-1.61(5 \mathrm{H}, \mathrm{m}, \mathrm{H}-5,7 \mathrm{a}, 7 \mathrm{~b}, 8 \mathrm{a}, 8 \mathrm{~b}), 1.64(1 \mathrm{H}, \mathrm{ddd}, J=12,4,2 \mathrm{~Hz}, \mathrm{H}-$ $2 \mathrm{eq}), 1.88(1 \mathrm{H}$, dddd, $J=12,11,4,2 \mathrm{~Hz}, \mathrm{H}-4 \mathrm{eq}), 3.65(1 \mathrm{H}$, sextet, $J=6 \mathrm{~Hz}$, $\mathrm{H}-10), 3.69(1 \mathrm{H}, \mathrm{tt}, J=12,4 \mathrm{~Hz}, \mathrm{H}-3) ;{ }^{13} \mathrm{C}-\mathrm{NMR}\left(\mathrm{CD}_{3} \mathrm{OD}\right)$ : see Table 1 ; HR-FAB-MS (negative-ion mode) $\mathrm{m} / \mathrm{z}: 213.1870[\mathrm{M}-\mathrm{H}]^{-}$(Calcd for $\mathrm{C}_{13} \mathrm{H}_{25} \mathrm{O}_{2}:$ :213.1855). D-Glucose, $[\alpha]_{\mathrm{D}}^{21}+42.9^{\circ}\left(c=0.23, \mathrm{H}_{2} \mathrm{O}, 24 \mathrm{~h}\right.$ after being dissolved in the solvent).

Preparation of the $(R)$ - and $(S)$-MTPA Esters $(5 b, c)$ from 5a A solution of $5 \mathbf{a}(3.1 \mathrm{mg})$ in $1 \mathrm{ml}$ of dehydrated $\mathrm{CH}_{2} \mathrm{Cl}_{2}$ was reacted with $(R)$ MTPA $\left(42 \mathrm{mg}\right.$ ) in the presence of $N, N^{\prime}$-dicyclohexylcarbodiimide (DCC) $(31 \mathrm{mg})$ and $4-N, N^{\prime}$-dimethylaminopyridine (DMAP) $(15 \mathrm{mg})$, and the mixture was occasionally stirred at $25^{\circ}$ for $30 \mathrm{~min}$. After the addition of $1 \mathrm{ml}$ each of $\mathrm{H}_{2} \mathrm{O}$ and $\mathrm{CH}_{2} \mathrm{Cl}_{2}$, the solution was washed with $5 \% \mathrm{HCl}(1 \mathrm{ml})$, $\mathrm{NaHCO}_{3}$-saturated $\mathrm{H}_{2} \mathrm{O}(1 \mathrm{ml})$, and brine $(1 \mathrm{ml})$ successively. The organic layer was dried over $\mathrm{Na}_{2} \mathrm{SO}_{4}$ and then evaporated under reduced pressure. The residue was purified by prep. TLC [silica gel $(0.25 \mathrm{~mm}$ thickness, applied for $18 \mathrm{~cm}$ and developed with $\mathrm{CHCl}_{3}-\left(\mathrm{CH}_{3}\right)_{2} \mathrm{CO}(9: 1)$ for $9 \mathrm{~cm}$ and eluted with $\left.\mathrm{CHCl}_{3}-\mathrm{MeOH}(9: 1)\right)$ to furnish the ester, $\mathbf{5 b}(7.6 \mathrm{mg}, 81 \%)$. Through a similar procedure, $\mathbf{5 c}(7.1 \mathrm{mg}, 76 \%)$ was prepared from $\mathbf{5 a}$ $(3.1 \mathrm{mg})$ using of $(S)$-MTPA $(43 \mathrm{mg})$, DCC $(29 \mathrm{mg})$ and 4-DMAP $(15 \mathrm{mg})$.

$(3 R, 5 R, 6 S, 9 R)$-Megastigman-3,9-diol 3,9-di-( $R$ )-MTPA Ester (5b): Amorphous powder; ${ }^{1} \mathrm{H}-\mathrm{NMR}\left(\mathrm{CDCl}_{3}\right) \delta: 0.559(1 \mathrm{H}$, ddd, $J=11,5,3 \mathrm{~Hz}, \mathrm{H}-6)$, $0.836\left(3 \mathrm{H}, \mathrm{s}, \mathrm{H}_{3}-11 \mathrm{ax}\right), 0.883\left(3 \mathrm{H}, \mathrm{s}, \mathrm{H}_{3}-12 \mathrm{eq}\right), 0.951\left(3 \mathrm{H}, \mathrm{d}, J=6 \mathrm{~Hz}, \mathrm{H}_{3}-\right.$ 13), $1.15(1 \mathrm{H}, \mathrm{q}, J=12 \mathrm{~Hz}, \mathrm{H}-4 \mathrm{ax}), 1.23(1 \mathrm{H}, \mathrm{t}, J=12 \mathrm{~Hz}, \mathrm{H}-2 \mathrm{ax}), 1.27(3 \mathrm{H}$, 
d, $\left.J=6 \mathrm{~Hz}, \mathrm{H}_{3}-10\right), 1.44-1.75(5 \mathrm{H}, \mathrm{m}, \mathrm{H}-5,7 \mathrm{a}, 7 \mathrm{~b}, 8 \mathrm{a}, 8 \mathrm{~b}), 1.72(1 \mathrm{H}, \mathrm{ddd}$, $J=12,4,2 \mathrm{~Hz}, \mathrm{H}-2 \mathrm{eq}), 2.05$ ( $1 \mathrm{H}$, dddd, $J=12,11,4,2 \mathrm{~Hz}, \mathrm{H}-4 \mathrm{eq}), 3.52$ (3H, q, $\left.J=1 \mathrm{~Hz},-\mathrm{OCH}_{3}\right), 3.54\left(3 \mathrm{H}, \mathrm{q}, J=1 \mathrm{~Hz},-\mathrm{OCH}_{3}\right), 5.07(1 \mathrm{H}$, sextet, $J=6 \mathrm{~Hz}, \mathrm{H}-10), 5.12(1 \mathrm{H}, \mathrm{tt} J=12,4 \mathrm{~Hz}, \mathrm{H}-3), 7.38-7.51(6 \mathrm{H}, \mathrm{m}$, aromatic protons), $7.52-7.55(4 \mathrm{H}, \mathrm{m}$, aromatic protons); HR-FAB-MS (positive-ion mode, $m$-nitrobenzyl alcohol as a matrix) $m / z$ : $669.2647[\mathrm{M}+\mathrm{Na}]^{+}(+\mathrm{NaI})$ (Calcd for $\mathrm{C}_{33} \mathrm{H}_{40} \mathrm{O}_{6} \mathrm{~F}_{6} \mathrm{Na}$ : 669.2627).

$(3 R, 5 R, 6 S, 9 R)$-Megastigman-3,9-diol 3,9-di-( $S)$-MTPA Ester (5c): Amorphous powder; ${ }^{1} \mathrm{H}-\mathrm{NMR}\left(\mathrm{CDCl}_{3}\right) \delta: 0.497(1 \mathrm{H}, \mathrm{ddd}, J=11,5,3 \mathrm{~Hz}, \mathrm{H}-6)$, $0.774\left(3 \mathrm{H}, \mathrm{s}, \mathrm{H}_{3}-11 \mathrm{ax}\right), 0.821$ (3H, s, $\left.\mathrm{H}_{3}-12 \mathrm{eq}\right), 0.887\left(3 \mathrm{H}, \mathrm{d}, J=6 \mathrm{~Hz}, \mathrm{H}_{3}-\right.$ 13), $1.02(1 \mathrm{H}, \mathrm{q}, J=12 \mathrm{~Hz}, \mathrm{H}-4 \mathrm{ax}), 1.29(1 \mathrm{H}, \mathrm{t}, J=12 \mathrm{~Hz}, \mathrm{H}-2 \mathrm{ax}), 1.34(3 \mathrm{H}$, d, $\left.J=6 \mathrm{~Hz}, \mathrm{H}_{3}-10\right), 1.43-1.75(5 \mathrm{H}, \mathrm{m}, \mathrm{H}-5,7 \mathrm{a}, 7 \mathrm{~b}, 8 \mathrm{a}, 8 \mathrm{~b}), 1.75(1 \mathrm{H}$, ddd, $J=12,4,2 \mathrm{~Hz}$, , H-2eq), 1.94 (1H, dddd, $J=12,11,4,2 \mathrm{~Hz}, \mathrm{H}-4 \mathrm{eq}), 3.53$ $\left(3 \mathrm{H}, \mathrm{q}, J=1 \mathrm{~Hz},-\mathrm{OCH}_{3}\right), 3.56\left(3 \mathrm{H}, \mathrm{q}, J=1 \mathrm{~Hz},-\mathrm{OCH}_{3}\right), 5.08(1 \mathrm{H}$, sextet, $J=6 \mathrm{~Hz}, \mathrm{H}-9), 5.11(1 \mathrm{H}, \mathrm{tt}, J=4,12 \mathrm{~Hz}, \mathrm{H}-3), 7.37-7.43(6 \mathrm{H}, \mathrm{m}$, aromatic protons), 7.50-7.56 (4H, m, aromatic protons); HR-FAB-MS (positive-ion mode, $m$-nitrobenzyl alcohol as a matrix) $m / z: 669.2617[\mathrm{M}+\mathrm{Na}]^{+}(+\mathrm{NaI})$ (Calcd for $\mathrm{C}_{33} \mathrm{H}_{40} \mathrm{O}_{6} \mathrm{~F}_{6} \mathrm{Na}$ : 669.2627).

Enzymatic Hydrolysis of 6 to $\mathbf{6 a}$ Compound $6(11.0 \mathrm{mg})$ was hydrolyzed by emulsin $(10 \mathrm{mg})$ in $2 \mathrm{ml}$ of $\mathrm{H}_{2} \mathrm{O}$ at $37^{\circ} \mathrm{C}$ for $12 \mathrm{~h}$. The reaction mixture was concentrated and then subjected to silica gel column $(20 \mathrm{~g}$, $\Phi=15 \mathrm{~mm}, \mathrm{~L}=20 \mathrm{~cm})$ chromatography with $\mathrm{CHCl}_{3}(150 \mathrm{ml}), \mathrm{CHCl}_{3}-\mathrm{MeOH}$ $(19: 1,150 \mathrm{ml}, 9: 1,100 \mathrm{ml}, 7: 3,300 \mathrm{ml}), 10 \mathrm{ml}$ fractions being collected. The aglycone (6a) and D-glucose were recovered in fractions 18-24 (5.7 $\mathrm{mg}, 91 \%)$ and $41-49(3.4 \mathrm{mg}, 65 \%)$, respectively. Aglycone (6a): Amorphous powder; $[\alpha]_{\mathrm{D}}^{21}-13.2^{\circ}(c=0.38, \mathrm{MeOH}) ;{ }^{1} \mathrm{H}-$ and ${ }^{13} \mathrm{C}-\mathrm{NMR}$ spectral data are essentially the same as those of 5a. HR-FAB-MS (negative-ion mode) $m / z: 213.1840[\mathrm{M}-\mathrm{H}]^{-}$(Calcd for $\mathrm{C}_{13} \mathrm{H}_{25} \mathrm{O}_{2}: 213.1855$ ). D-Glucose, $[\alpha]_{\mathrm{D}}^{21}+44.1^{\circ}\left(c=0.23, \mathrm{H}_{2} \mathrm{O}, 24 \mathrm{~h}\right.$ after being dissolved in the solvent $)$

Preparation of the $(R)$ - and $(S)$-MTPA Esters $(6 b, c)$ from 6a In a similar manner as from $\mathbf{5 a}$ to $\mathbf{5 b}$ and $\mathbf{5 c}, \mathbf{6 b}$ and $\mathbf{6 c}$ were prepared from $\mathbf{6 a}$ $(2.8 \mathrm{mg}$ each) with the respective amounts of the reagents, $(R)$ - and $(S)$ MTPA (39, $37 \mathrm{mg}$ ), 1-ethyl-3-(3-dimethylaminopropyl)carbodiimide hydrochloride $(29,33 \mathrm{mg})$ and DMAP $(14,15 \mathrm{mg})$. A usual workup gave $7.5 \mathrm{mg}$ $(87 \%)$, and $7.6 \mathrm{mg}(88 \%)$ of the diesters, respectively.

$(3 R, 5 R, 6 S, 9 R)$-Megastigman-3,9-diol 3,9-di- $(R)$ and $(S)$-MTPA Esters $(\mathbf{6 b}, \mathbf{c})$ : Amorphous powder; ${ }^{1} \mathrm{H}-\mathrm{NMR}$ data of $\mathbf{6 b}$ and $\mathbf{6 c}$ were essentially the same as those of $\mathbf{5 b}$ and $\mathbf{5 c}$, respectively. 3,9-Di- $(R)-\mathrm{MTPA}$ ester $(\mathbf{6} \mathbf{b})$ : HR-FAB-MS (positive-ion mode, $m$-nitrobenzyl alcohol as the matrix) $m / z: 669.2621[\mathrm{M}+\mathrm{Na}]^{+}$(+NaI) (Calcd for $\mathrm{C}_{33} \mathrm{H}_{40} \mathrm{~F}_{6} \mathrm{NaO}_{6}: 669.2627$ ). 3,9-Di-( $S$ )-MTPA ester (6c): HR-FAB-MS (positive-ion mode, $m$-nitrobenzyl alcohol as the matrix) $\mathrm{m} / \mathrm{z}$ : $669.2634[\mathrm{M}+\mathrm{Na}]^{+}(+\mathrm{NaI})(\mathrm{Calcd}$ for $\mathrm{C}_{33} \mathrm{H}_{40} \mathrm{O}_{6} \mathrm{~F}_{6} \mathrm{Na}$ : 669.2627).

Enzymatic Hydrolysis of 8 to 8 a Compound 8 (4.8 $\mathrm{mg})$ was hydrolyzed with crude hesperidinase $(20 \mathrm{mg})$ in $2 \mathrm{ml}$ of $\mathrm{H}_{2} \mathrm{O}$ at $37^{\circ} \mathrm{C}$. The reaction was monitored by TLC. At $12 \mathrm{~h}$ and $36 \mathrm{~h}$, further amounts of crude hesperidinase $(40 \mathrm{mg})$ were added. At $60 \mathrm{~h}$ after the initiation of hydrolysis, the reaction mixture was partitioned with EtOAc $(2 \mathrm{ml} \times 4)$. The organic layer was dried over $\mathrm{Na}_{2} \mathrm{SO}_{4}$ and then evaporated to give an aglycone (8a) $(1.2 \mathrm{mg}, 60 \%)$. Aglycone (8a): Amorphous powder; ${ }^{1} \mathrm{H}-\mathrm{NMR}\left(\mathrm{CD}_{3} \mathrm{OD}\right) \delta$ : $1.04\left(3 \mathrm{H}, \mathrm{s}, \mathrm{H}_{3}-12 \mathrm{eq}\right), 1.05\left(3 \mathrm{H}, \mathrm{s}, \mathrm{H}_{3}-11 \mathrm{ax}\right), 1.17\left(3 \mathrm{H}, \mathrm{d}, J=6 \mathrm{~Hz}, \mathrm{H}_{3}-10\right)$, $1.38(1 \mathrm{H}, \mathrm{t}, J=12 \mathrm{~Hz}, \mathrm{H}-2 \mathrm{ax}), 1.43-1.53(3 \mathrm{H}, \mathrm{m}, \mathrm{H}-7 \mathrm{a}, 8 \mathrm{a}, 8 \mathrm{~b}), 1.63(3 \mathrm{H}$, s, $\left.\mathrm{H}_{3}-13\right), 1.68(1 \mathrm{H}, \mathrm{ddd}, J=12,5,2 \mathrm{~Hz}, \mathrm{H}-4 \mathrm{eq}), 1.71(1 \mathrm{H}, \mathrm{m}, \mathrm{H}-7 \mathrm{~b}), 1.93$ $(1 \mathrm{H}, \mathrm{br}$ dd, $J=17,10 \mathrm{~Hz}, \mathrm{H}-4 \mathrm{ax}), 2.19(1 \mathrm{H}, \mathrm{br} \mathrm{dd}, J=17,6 \mathrm{~Hz}, \mathrm{H}-4 \mathrm{eq}), 3.71$ $(1 \mathrm{H}$, sextet, $J=6 \mathrm{~Hz}, \mathrm{H}-9), 3.85(1 \mathrm{H}, \mathrm{m}, \mathrm{H}-3) ;{ }^{13} \mathrm{C}-\mathrm{NMR}\left(\mathrm{CD}_{3} \mathrm{OD}\right)$ : see Table 1; HR-FAB-MS (negative-ion mode) $\mathrm{m} / z: 211.1671[\mathrm{M}-\mathrm{H}]^{-}$(Calcd for $\left.\mathrm{C}_{13} \mathrm{H}_{23} \mathrm{O}_{2}: 211.1698\right)$.

Preparation of the $(R)$ - and $(S)$-MTPA Esters $(8 b, c)$ from 8a In a similar manner to as from $\mathbf{5 a}$ to $\mathbf{5 b}$ and $\mathbf{5 c}, \mathbf{8 b}$ and $\mathbf{8 c}$ were prepared from $\mathbf{8 a}$ $(0.6 \mathrm{mg}$ each) with the respective amounts of the reagents, $(R)$ - and $(S)$ -
MTPA (28 and $27 \mathrm{mg}$ ), DCC (20 and $22 \mathrm{mg}$ ), and DMAP (12, $10 \mathrm{mg}$ ). The usual workup gave $1.3 \mathrm{mg}$ of $\mathbf{8 b}(72 \%)$ and $1.2 \mathrm{mg}$ of $\mathbf{8 c}(67 \%)$, respectively.

$(3 S, 9 S)$-Megastigman-5-en-3,9-diol 3,9-di-( $R)$-MTPA Ester (8b): Amorphous powder; ${ }^{1} \mathrm{H}-\mathrm{NMR}\left(\mathrm{CDCl}_{3}\right) \delta: 0.941\left(1 / 3 \mathrm{H}, \mathrm{s}, \mathrm{H}_{3}-12\right.$, minor $), 0.978$ (1/3H, s, $\mathrm{H}_{3}-11$, minor), 1.01 (2/3H, s, $\mathrm{H}_{3}-12$, major), $1.06\left(2 / 3 \mathrm{H}, \mathrm{s}, \mathrm{H}_{3}-11\right.$, major), $1.29\left(2 / 3 \mathrm{H}, \mathrm{d}, J=6 \mathrm{~Hz}, \mathrm{H}_{3}-10\right.$, major), $1.36\left(1 / 3 \mathrm{H}, \mathrm{d}, J=6 \mathrm{~Hz}, \mathrm{H}_{3}-10\right.$, minor), $3.53\left(2 / 3 \mathrm{H}, \mathrm{q}, J=1 \mathrm{~Hz},-\mathrm{OCH}_{3}\right.$, major), $3.55(3 \mathrm{H}, \mathrm{q}, J=1 \mathrm{~Hz}$, $\left.-\mathrm{OCH}_{3}\right), 3.57\left(1 / 3 \mathrm{H}, \mathrm{q}, J=1 \mathrm{~Hz},-\mathrm{OCH}_{3}\right.$, minor), 5.11 (1H, sextet, $\left.\mathrm{H}-9\right)$, $5.23(1 \mathrm{H}, \mathrm{m}, \mathrm{H}-3), 7.38-7.41(6 \mathrm{H}, \mathrm{m}$, aromatic protons $), 7.51-7.54(4 \mathrm{H}$, $\mathrm{m}$, aromatic protons), due to overlapping of signals, olefinic methyl and methylene protons could not be assigned; HR-FAB-MS (positive-ion mode, $m$-nitrobenzyl alcohol as the matrix) $m / z: 667.2484[\mathrm{M}+\mathrm{Na}]^{+}(+\mathrm{NaI})$ (Calcd for $\mathrm{C}_{32} \mathrm{H}_{38} \mathrm{O}_{7} \mathrm{~F}_{6} \mathrm{Na}$ : 667.2470).

$(3 S, 9 R)$-Megastigman-5-en-3,9-diol 3,9-di-( $S)$-MTPA Ester (8c): Amorphous powder; ${ }^{1} \mathrm{H}-\mathrm{NMR}\left(\mathrm{CDCl}_{3}\right) \delta: 0.931\left(2 / 3 \mathrm{H}, \mathrm{s}, \mathrm{H}_{3}-12\right.$, major), 0.978 ( $1 / 3 \mathrm{H}, \mathrm{s}, \mathrm{H}_{3}-12$, minor), 1.02 ( $2 / 3 \mathrm{H}, \mathrm{s}, \mathrm{H}_{3}-11$, major), $1.03\left(1 / 3 \mathrm{H}, \mathrm{s}, \mathrm{H}_{3}-11\right.$, minor), $1.30\left(1 / 3 \mathrm{H}, \mathrm{d}, J=6 \mathrm{~Hz}, \mathrm{H}_{3}-10\right.$, minor), $1.36\left(2 / 3 \mathrm{H}, \mathrm{d}, J=6 \mathrm{~Hz}, \mathrm{H}_{3}-10\right.$, major), $1.58\left(2 / 3 \mathrm{H}, \mathrm{s}, \mathrm{H}_{3}-13\right.$, major $), 3.52\left(1 / 3 \mathrm{H}, \mathrm{q}, J=1 \mathrm{~Hz},-\mathrm{OCH}_{3}\right.$, minor), $3.54\left(3 \mathrm{H}, \mathrm{q}, J=1 \mathrm{~Hz},-\mathrm{OCH}_{3}\right), 3.57\left(2 / 3 \mathrm{H}, \mathrm{q}, J=1 \mathrm{~Hz},-\mathrm{OCH}_{3}\right.$, major), $5.13(1 \mathrm{H}$, sextet, $J=6 \mathrm{~Hz}, \mathrm{H}-9), 5.23(1 \mathrm{H}, \mathrm{m}, \mathrm{H}-3), 7.37-7.40(6 \mathrm{H}$, $\mathrm{m}$, aromatic protons), $7.52-7.54(4 \mathrm{H}, \mathrm{m}$, aromatic protons), due to overlapping of signals, olefinic methyl and methylene protons could not be assigned; HR-FAB-MS (positive-ion mode, $m$-nitrobenzyl alcohol as the matrix) $m / z$ : $667.2488[\mathrm{M}+\mathrm{Na}]^{+}(+\mathrm{NaI})\left(\mathrm{Calcd}\right.$ for $\mathrm{C}_{32} \mathrm{H}_{38} \mathrm{O}_{6} \mathrm{~F}_{6} \mathrm{Na}$ : 667.2470).

Acknowledgements The authors are grateful for the access to the superconducting NMR instrument in the Analytical Center of Molecular Medicine of Hiroshima University Faculty of Medicine. This work was supported in part by a Grant-in-Aid from the Ministry of Education, Culture, Sports, Science and Technology of Japan (No. 13672216). Thanks are also due to the Okinawa Foundation for financial support through an Okinawa Research Promotion Award (H.O.).

\section{References}

1) a) Kitamura S., Murata G., "Coloured Illustrations of Woody Plants of Japan,” Vol. I, Hoikusha Publishing Co., Ltd., Osaka, 1971, pp. 106$112 ; b$ ) Hatusima S., "Flora of the Ryukyus," Okinawa Society of Biological Education and Research, Naha, Okinawa, 1975, pp. 463-468.

2) Harborne J. B., Baxter H., Moss G. P., "Phytochemical Dictionary," 2nd ed., Taylor \& Francis Ltd., London, 1999, p. 556.

3) "Primary Chinese Herbs Pictorial Illustrated," People's Hygiene Press, ed., Yuuki Press Co., Ltd., Kyoto, 1982, pp. 384-385.

4) Bloor S. J., Qi L., J. Nat. Prod., 57, 1354-1360 (1994).

5) a) Zhong X.-N., Otsuka H., Ide T., Hirata E., Takushi A., Takeda Y., Phytochemistry, 46, 943-946; b) Zhong X.-N., Otsuka H., Ide T., Hirata E., Takeda Y., ibid., 49, 1777-1778 (1998); c) Zhong X.-N., Otsuka H., Ide T., Hirata E., Takushi A., Takeda Y., ibid., 49, 2149$2153(1998)$; d) Zhong X.-N., Otsuka H., Ide T., Hirata E., Takeda Y., ibid., 52, 923-927 (1999).

6) a) Inada A., Nakamura Y., Konishi M., Murata H., Kitamura F., Toya H., Nakanishi T., Chem. Pharm. Bull., 39, 2437-2439 (1991); b) Tamaki A., Otsuka H., Ide T., J. Nat. Prod., 62, 1074-1076 (1999).

7) Klyne W., Biochem. J., 47, xli (1950).

8) Kasai R., Suzuno M., Asakawa J., Tanaka O., Tetrahedron Lett., 175178 (1977).

9) Otsuka H., Yao M., Kamada K., Takeda Y., Chem. Pharm. Bull., 43, 754-759 (1995).

10) Ohtani I., Kusumi T., Kashman Y., Kakisawa H., J. Am. Chem. Soc., 113, 4092- 4096 (1991).

11) Otsuka H., Phytochemistry, 37, 461-465 (1994). 